\title{
Ocorrência de lesões podais em rebanho Jersey no norte do Paraná
}

Isadora Naomi Vieira Ogawa, Marcela dos Santos Ribeiro, Erick Henrique Pissinati Pelaquim, Aline Tramontini Zanluchi Queiroz, Gustavo Rodrigues Queiroz

Universidade do Norte do Paraná (UNOPAR), Londrina, PR, Brasil

*Autor correspondente

e-mail: gustavorodriguesqueiroz11@gmail.com

\section{Resumo}

Afecções dos dígitos dos bovinos determinam importantes prejuízos à cadeia produtiva leiteira, devido ao custo de tratamento e reposição das vacas descartadas, além da diminuição dos índices produtivos e reprodutivos. Para conseguir realizar um programa preventivo de lesões podais em um rebanho, primeiramente deve-se conhecer quais são as principais causas de lesões podais que estão ocorrendo nesta propriedade. Por este motivo, deve ser feita a inspeção de todos os dígitos de todas as vacas em lactação, e não apenas dos animais que estão claudicando.0 objetivo deste trabalho foi classificar as lesões podais em um rebanho Jersey em lactação. Foram avaliadas 73 vacas da raça Jersey, com idade variando entre 2 - 10 anos, em uma propriedade leiteria do município de Tamarana, região norte do Paraná. As vacas eram mantidas em regime de confinamento durante o dia e permaneciam em piquetes de Tifton (Cynodon dactylon) durante a noite. A área de confinamento era composta entre área coberta e com piso concretado e área descoberta com chão de terra. 0 escore de claudicação foi avaliado em todas as vacas e, em seguida, os animais foram colocados em tronco de contenção tombador, próprio para o casqueamento de bovinos. Todos os dígitos e espaços interdigitais foram limpos e uma fina camada da sola do casco foi removida com a intenção de facilitar o exame e a visualização das lesões da região da sola e da linha branca. Após o exame de cada dígito, as lesões encontradas foram classificadas de acordo com os tipos de lesões. Apenas $28,7 \%$ (21/73) das vacas apresentaram algum grau de claudicação, que foram classificadas nos escores II (4/73; 5,5\%), III (4/73; 5,5\%), IV (9/73; 12,3\%) e V (4/73; 5,5\%). Foram observadas 970 lesões nos 584 dígitos examinados, o que correspondeu a 13,2 lesões por vaca. Os dígitos dos membros anteriores (55,3\%) continham mais lesões do que os posteriores (44,7\%); os dígitos mediais (304/536; 56,7\%) dos membros anteriores apresentaram mais lesões do que os laterais (232/536; 43,3\%); e nos membros posteriores, a distribuição das lesões foram praticamente equivalentes, pois os dígitos mediais continham 49,1\% (213/434) 
das lesões e os dígitos laterais 50,9\% (221/434). As principais lesões diagnosticadas foram a erosão de talão (523/970; 53,8\%), doença da linha branca $(187 / 970 ; 19,3 \%)$, sola dupla $(121 / 970 ; 12,6 \%)$, hemorragia de sola (25/970; 2,6\%), úlcera de sola $(17 / 970 ; 1,7 \%)$ e outras lesões $(97 / 970 ; 10,0 \%)$. A ocorrência de lesões podais nas vacas avaliadas foi de $100 \%$, fato explicado pela inexistência de casqueamento preventivo dos animas. Múltiplas lesões podais podem ocorrer no mesmo animal, sem causar claudicação, exaltando a necessidade do exame sistemático dos dígitos. 